\title{
ADYNAMIC GRACILOPLASTY FOR FECAL INCONTINENCE IN AN ADULT AFTER ANAL ATRESIA AND FAILED CORRECTIONS IN INFANCY - A CASE REPORT
}

\author{
Narimantas Evaldas Samalavičius ${ }^{1,2}$, Vitalija Nutautiené ${ }^{1}$, Miglė Kibranciené ${ }^{1}$, \\ Vitalijus Eismontas', Giedrius Kuprys ${ }^{1}$, Vaidotas Turskis ${ }^{1}$, Algirdas Šlepavičius ${ }^{\mathbf{1}}$ \\ ${ }^{1}$ Department of Surgery, Klaipeda University Hospital, Lithuania, ${ }^{2}$ Clinic of Internal, \\ Family Medicine and Oncology, Faculty of Medicine, Vilnius University, Lithuania
}

Key words: fecal incontinence, gracilis muscle, graciloplasty.

\begin{abstract}
Summary
Fecal incontinence after surgeries for anal atresia is not rare. One of the possible treatment alternatives - adynamic graciloplasty. We present a case of an adult patient to whom adynamic gracyloplasty was performed for fecal incontinence after single attempt of sphincter repair in childhood. There was a symptomatic improvement postoperatively, as confirmed by Wexner and FISI index. Adynamic graciloplasty could be more often used as a treatment option of fecal incontinence in adult patients with history of anal atresia.
\end{abstract}

\section{Introduction}

Fecal incontinence is a very distressing condition, largely affecting patient's quality of life. There may be many etiologies causing this symptom, but one of the possible causes is congenital anal atresia - not rarely early repair in infancy is unable to correct this problem. The use of gracilis muscle for fecal incontinence in this particular group of patients is known more than for a half of century (1). A dynamic graciloplasty for various etiologies of fecal incontinence has been more recently introduced as a very promising alternative (2). In time, this technique was reported to have high complication and reoperation rate, as well as significant failure rate (3). We report a case of successful adynamic graciloplasty in an adult female with a history of congenital anal atresia.

\section{Case report}

Patient A.D., female, born 1969, was referred because of fecal incontinence and mucosal prolapse in September 2017. Patient was born with anal atresia, underwent single attempt of repair during infancy, but the whole life was suffering of fecal incontinence.

Patient was investigated. At rest, anus was opened for 1,5-2 centimeters, and on straining there is a semicircular prolapse of several centimeters of rectal mucosa of anterior wall. She was several times operated for this prolapse and anal polyps, which were inflammatory on histology and likely related with constant contact with underwear. Proctoscopy did not reveal any additional pathology, and colonoscopy was normal. Despite these symptoms were from early childhood and patient lived with them, now patient claimed impaired quality of live and social adaptation restrictions, and was seeking for solution of her condition.

Prior our surgery, her Wexner score was 19 and FISI index was 44.

Patient was operated on 201711 08, an unstimulated graciloplasty was performed. The operation was carried out in lithotomy position. Through three short separate incisions in the right thigh musculus gracilis was harvested with the tendon (Fig. 1) up to the level where anterior branch of obturator nerve enters the muscle, in proximity to vascular pedicle - terminal branch of circumflex femoral artery (Fig. 2) approximately $10 \mathrm{~cm}$ below pubic tubercle. The muscle was threated forward to the perineal area were oval incision was made (Fig. 3) and wrapped around the anus using additional small incision below the tip of the coccygis (Fig. 4 ), and tendon of the gracilis muscle was fixed with the 1.0 nylon interrupted sutures to the periosteum of lower surface of ischial tuberosity on the same side (right side). Meticulous hemostasis was performed and wounds closed in layers, a penrose drain left in the bed of the gracilis muscle in lower thigh for 24 hours. Postoperative course was uneventful.

After 4 weeks, a course of low frequency electric external stimulation in the area around the neurovascular bundle in the thigh was performed. 

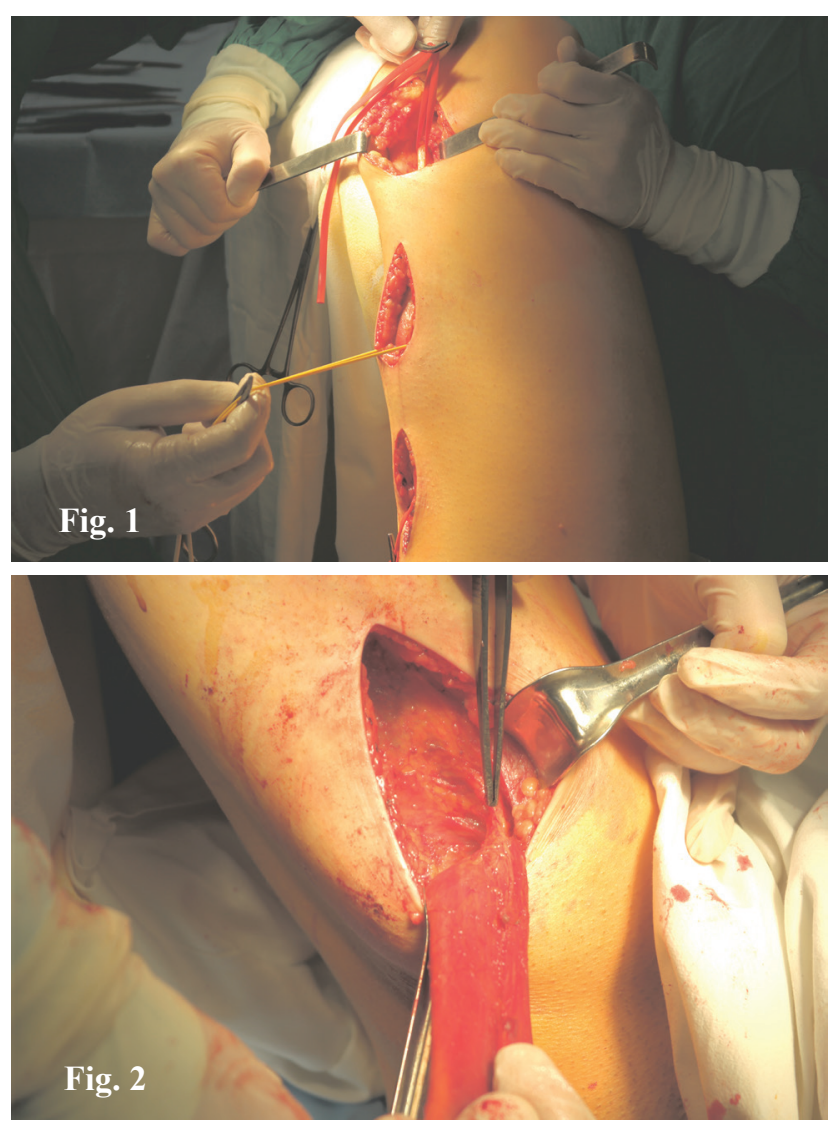

Patient was evaluated 3 months postoperatively. On inspection, her anus was closed at rest. She stated moderate improvement in her continence and quality of life, her Wexner score was 10 and FISI score was 32.

\section{Discussion}

A large number of perioperative complications, which mostly are infective, technical and functional, as well as modest functional results did not make dynamic graciloplasty a very attractive procedure $(4,5)$, even bearing in mind that for most of there patients stoma is the only possible alternative. It is related with learning curve effect and complexity of the procedure itself. The reasonable idea seems to be to substitute electrostimulation effect without implantation of sophisticated device simply by applying external electric stimulation postoperatively (6), which was done in our case as well. External low frequency nerve stimulation can be combined with biofeedback training sessions. There are records in the literature that type II muscle can be transformed into non-fatigue type I muscle by regular electric nerve stimulation (2). We used external postoperative nerve stimulation technique described by Niriella DA and Deen
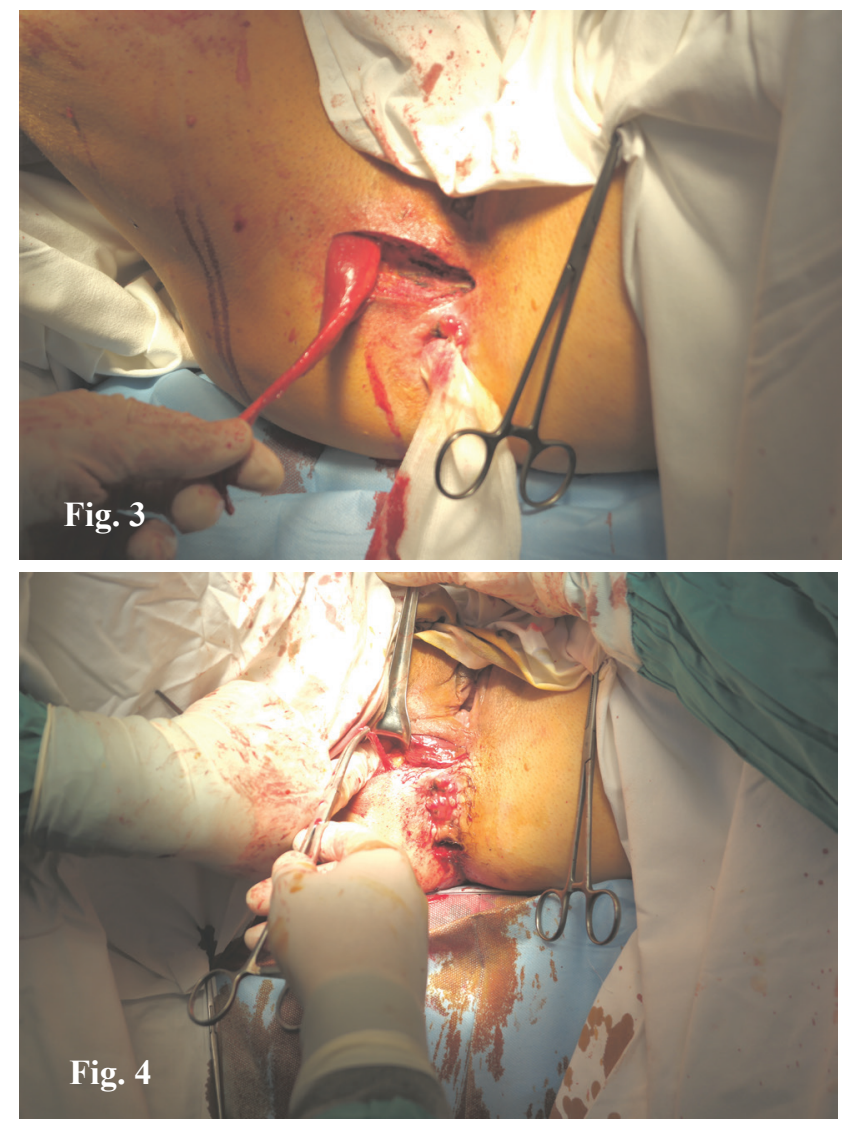

KI (7), as they have as well demonstrated that with this adynamic graciloplasty technique functional results are equivalent to stimulated graciloplasty. Walega $P$ and colleagues (8) made an analysis of their results with end-stage fecal incontinence, 7 patients with dynamic and 13 with adynamic graciloplasty. At 12 months, there was significant and similar improvement in both groups, with better squeeze pressures in adynamic graciloplasty group. In conclusion, with much less cost to achieve same results adynamic graciloplasty seemed to be a reasonable method of choice. In analysis of the literature recently done by Barisic $\mathrm{G}$ and Krivokapic $\mathrm{Z}$ (9), adynamic graciloplasty was effective in on an average $50 \%$ of cases, dynamic - appr. $60 \%$, so hardly there was any difference again. Up to date, favorable reports are published in the literature on success of adynamic graciloplasty, mostly from Asia, though as a rule with small sample size and retrospective in nature $(10,11,12)$. In our case, as well demonstrated by Shi GG at coauthors (12), we used v type of graciloplasty in order to avoid postoperative defecation problems, and we were able to record successful functional outcome. 


\section{Conclusion}

Adynamic graciloplasty could be more often used as a treatment option of fecal incontinence in adult patients with history of anal atresia.

\section{References}

1. Pickrell KL, Broadbent TR, Masters FW, Metzger JT. Construction of a rectal sphincter and restoration of anal incontinence by transplanting the gracilis muscle: a report of four cases in children. Ann Surg 1952;135:853-62.

https://doi.org/10.1097/00000658-195206000-00010

2. Baeten CG, Geerds BP, Adang EM, Heineman E, Konsten J, Engel GL, Kester AD, Spaans F, Soeters PB. N Engl J Med 1995;332:1600-1605.

https://doi.org/10.1056/NEJM199506153322403

3. Penninckx F on behalf of Belgian section of colorectal surgery. Belgian experience with dynamic graciloplasty for fecal incontinence.Br J Surg 2004;91:872-8

https://doi.org/10.1002/bjs.4568

4. Belyaev O, Muller C, Uhl W. Neosphincter surgery for fecal incontinence: a critical and unbiased review of the relevant literature. Surgery Today 2006;36(4):295-303.

https://doi.org/10.1007/s00595-005-3159-4

5. Mander BJ, Wexner SD, Williams NS, Bartolo DC, Lubowski DZ, Oresland T, Romano G, Keighley MRB. Preliminary results of a multicenter trial of the electricity stimulated gracilis neoanal sphincter. Br J Surg 1999;86:1543-8.

https://doi.org/10.1046/j.1365-2168.1999.01285.x

6. Zailani MHM, Azmi MN, Deen KI. Gracilis muscle as neoanal sphincter for faecal incontinence. Med J Malaysia 2010;65(1):66-7.

7. Niriella DA, Deen KI. Neosphincters in the management of faecal incontinence. Br J Surg 2000;87:1617-28.

https://doi.org/10.1046/j.1365-2168.2000.01605.x

8. Walega P, Romaniszyn M, Siarkiewizc B, Zelazny D. Dynamic versus adynamic graciloplasty in treatment of end-stage fecal incontinence: is the implantation of the pacemaker really necessary? 12-month follow-up in a clinical, physiological, and functional study. Gastroenterology Research and Practice 2015;ID698516

https://doi.org/10.1155/2015/698516
9. Barisic G, Krivokapic Z. Adynamic and dynamic muscle transposition techniques for anal incontinence. Gastroenterology Report 2014;2(2):98-105.

https://doi.org/10.1093/gastro/gou014

10. Kalra GDS, Sharma AK, Shende SK. Gracilis muscle transposition as a workhorse flap for anal incontinence: quality of life and functional outcomes in adults. Indian J Plastic Surg 2016;49(3):350-6.

https://doi.org/10.4103/0970-0358.197245

11. Chandrakasan C, Reddy V, Reddy D, Musunuru BR, Dasari V, Pagadala NNB. Role of adynamic graciloplasty in intractable fecal incontinence: initial results from tertiary centre in South India. Int Surg J 2016;3(4):2146-9/

https://doi.org/10.18203/2349-2902.isj20163589

12. Shi GG, Wang H, Wang L, Zhang ZX, Wang H. Two different gracilis loops in graciloplasty of congenital fecal incontinence: a comparison of therapeutic effects. Ins J Colorectal Dis 2015;30:1391-7.

https://doi.org/10.1007/s00384-015-2274-y

\section{ADINAMINE் GRACILOPLASTIKA DE்L IŠMATŲ NELAIKYMO SUAUGUSIAM PO ATRESIO ANI IR NESĖKMINGŲ KOREKCIJŲ KÜDIKYSTĖJE. ATVEJO ANALIZE}

N.E.Samalavičius, V.Nutautienė, M.Kibrancienė, V.Eismontas, G.Kuprys, V.Turskis, A.Šlepavičius

Raktažodžiai: išmatų nelaikymas, grakštusis raumuo, graciloplastika.

Santrauka

Išmatų nelaikymas po operacijų dèl atresio ani yra neretas reiškinys. Viena iš galimų alternatyvų - adinaminè graciloplastika. Šiame straipsnyje pateikiama atvejo analizè, kuomet suaugusiai pacientei dèl pilno išmatų nelaikymo po buvusios operacijos kūdikystejje buvo atlikta adinaminè graciloplastika. Po operacijos pagerèjo išmatų laikymo funkcija, kuri vertinta Wexner ir FISI klausimynais. Manome, jog adinaminé graciloplastika galètų būti dažniau taikoma šiai pacientų grupei.

Adresas susirašinèti: narimantas.samalavicius@gmail.com

Gauta 2018-12-20 